\title{
Serious Games in High School Mathematics Lessons: An Embedded Case Study in Europe
}

\author{
Giuseppina Gerarda Barbieri ${ }^{1}$, Rosa Barbieri ${ }^{2}$, Roberto Capone ${ }^{1 *}$ \\ ${ }^{1}$ Department of Mathematics, University of Salerno, ITALY \\ 2 IIS "L. Da Vinci-Nitti", Potenza, ITALY
}

Received 1 Mar 2021 - Accepted 15 April 2021

\begin{abstract}
In this article, we will describe the embedded case study of the European project "E-Magic" carried out within the Erasmus + project and which involved 12-16 years old students and teachers from three nations: "Acharnes Special Education Vocational School" in Athens (Greece), IIS "L. Da VinciNitti", a high school in Potenza (Italy), and from Gabinete de Modernizao das Tecnologias Educativas (G.M.T.E.) in Madeira Islands (Portugal). The project is finalized to enhance Mathematical Competencies by Serious Games learning. We carried out both empirical qualitative and quantitative methods to highlight Serious Games' effectiveness, as a teaching methodology, in motivating students to learn mathematics. We also hypothesize that prompting a strategic way of thinking within a didactical intervention by game-approach could improve students' proving processes and support them in mathematical thinking production. Rabardel's cognitive ergonomics and the Technological Pedagogical Content Knowledge model are the lenses for reading educational experiments' data. Data seems to show that simulation helps students find alternative and creative solutions to problems. Therefore, Serious Games' use in education promotes significant changes and mental resources activation.
\end{abstract}

Keywords: serious game, case study, mathematical competencies, technological pedagogical content knowledge, instrumental genesis

\section{INTRODUCTION}

The world is changing, and technology is so infused with our lives that it has become an extension of our cognition (Clark, 2001). This fact has an enormous influence on the educational aspects and involves a constant evolution of the educational paradigms. The use of games plays a growing relevant role in the educational context and it is becoming increasingly widespread thanks to the possibility of integrating technology and teaching by mobile devices. Indeed, according to Devlin, "A game can provide a structure for the learning that takes place in the environment" (Devlin, 2011, p. 32). Also, Shaffer and Gee (2005) believe that bringing technological innovation into the classroom is necessary to design epistemic games. The authors define these games as follows: "Epistemic games are about knowledge, but they are about knowledge in action- about making knowledge, applying knowledge, and sharing knowledge". (Shaffer \& Gee, 2005, p. 16). That means we need to ensure that technology is well constructed to support cognition and learning.

Even I.C.T. (Information and Communication Technologies) has made its way as a school subject to meet technical skills' growing demands. According to (Brom et al., 2010), using technology in schools helps practical skills and facilitates teaching and learning. At the moment, there seems to be a rift between what students do for fun and what they are required to do at school. Shute et al. (2009) observe that the students who are struggling to work on school assignments are eager to play the video games they consider fun when finally freed from school. It is known that student engagement is strongly associated with academic achievement (Shute et al., 2009), making learning fun is a worthwhile endeavor. This is especially true for mathematics, although, at first glance, combining the concept of immersive gaming with mathematics seems to be a

(c) 2021 by the authors; licensee Modestum. This article is an open access article distributed under the terms and conditions of the Creative Commons Attribution License (http://creativecommons.org/licenses/by/4.0/). 


\section{Contribution to the literature}

- The study aims to analyze Serious Games' use in education.

- Through both empirical qualitative and quantitative methods, the study highlights Serious Games' effectiveness, as a teaching methodology, in motivating students to learn mathematics.

- The study applies Rabardel's cognitive ergonomics and the Technological Pedagogical Content Knowledge model for reading educational experiments' data.

misfit, and it takes careful planning and a lot of advanced knowledge to make this combination work. According to Forman (1989), students' opinions on math are a dry subject with not much connection to the real world, except that it is essential for university. So serious games find their natural place for the formation of knowledge. Their purpose is to create a new way of learning mathematics, increase students' motivation and self-efficacy beliefs outside of formal learning settings, and create a learning approach to help weaker learners. More concretely, serious games are real video game experiences. The explicit aim is education: their strength lies in combining the educational and learning aspects with the pleasure of playing. The student does not understand "Mathematics" for different reasons, but above all, because he knows "Mathematics mediated by his teacher" analyzed by D'Amore and Fandino Pinilla (2007) in technical details. At the same time, learners are more used to games in their everyday life and technology grows to be ever-present around us. So serious games can be used to increase motivation. Another fundamental advantage obtainable through serious games is that the user's behavior is measurable, and it allows for the collection of data based on the actions performed within the game. Serious games in mathematics can help schools tackle early school leaving (E.S.L.) and disadvantage and offer quality education, enabling all students' success, from the lowest to the highest end of the academic spectrum. Serious games can improve education, evaluation, and quality assurance.

Starting also from these assumptions, in this work, we will describe the embedded case study that involved 12-16 years old students and teachers from "Acharnes Special Education Vocational School" in Athens (Greece), "L. Da Vinci-Nitti", a high school in Potenza (Italy), and from Gabinete de Modernizao das Tecnologias Educativas (G.M.T.E.) in Madeira Islands (Portugal); in many cases, these students have special educational needs. This case study was included in an international project named "E-Magic", part of the more comprehensive European Erasmus+ project. In two years, 2017-2019, we developed a new and innovative educative game for mobile devices: Clash of wizardry, which aims is to contribute to the student's effective learning, to improve their school success, to promote inclusion, to bring students to S.T.E.M. areas and fight against school dropout rates. Our game is a tool for training operations and concepts inherent to resolving the 1st-degree equations. The specific goal is to reinforce mathematical skills addressed to high school students. We hope that it will become a tool that can support classwork to activate students in a non-traditional manner and help them acquire essential skills. It will be explicitly used also for disadvantaged learners. It also reduces the gap between students' mathematical abilities of southern Europe and northern Europe.

For those interested in the educational context apart from Europe, we suggest reading some other papers like Matos, J. M. (2020).

This paper will briefly describe our training experience and outline teachers' practice in their classrooms concerning this serious game. Besides, the impact on the improvement of mathematics learning is described.

This research focuses on two main questions; firstly, we wonder whether the use of serious games encourages better emotional dispositions towards mathematics and improves the teaching-learning process of the discipline; secondly, whether the use of serious games allows the teacher a reflective action on his teaching methodologies to encourage effective teaching of mathematics (Capone et al., 2020).

The results are remarkable: from the tests carried out on the students and from the analysis of the obtained data, a strong emotional involvement seems to emerge, overcoming epistemological obstacles in mathematics learning (Capone et al., 2020). From the quantitative results, we know that teachers like to integrate traditional teaching with more engaging and captivating education. The formative assessment test results reveal the didactic action's effectiveness in their classrooms. We look at a serious game as an instrument that mediates a collective activity in the sense of Rabardel's cognitive ergonomics. Furthermore, we understand the serious games for learning mathematics as an essential part of educational activities, including pedagogical, methodological, and technological aspects. The model of Technological Pedagogical Content Knowledge (described in Section Conceptual Framework) has been used as a lens for educational experiments' reading data.

The paper is organized as follows: in Section Conceptual Framework, we offer some examples of a didactic use of serious games in mathematical education; and then we briefly describe the Conceptual Framework that is a key for reading the analyzed data: Rabardel's 
Instrumental Genesis (1995) is supported to interpret the students' enhance in Mathematics; the Technological Pedagogical Content Knowledge (T.P.C.K.) framework helps us to understand the teachers' beliefs concerning the use of technology in the classroom; in Section Research Questions research questions are highlighted. In Section Project "E-MaGIC, the project and the participants are described. In Section Clash of Wizardry Instrumental Genesis, we describe the adopted methodology. In Section Experiment Design and Procedure, we describe the game design and the context in which the experimentation was carried out. Finally, in Section Findings, we give our findings, and in Section Conclusion, the conclusions.

This work was announced in a paper published in Italian in October 2019, see Barbieri et al. (2019). Moreover, we would like to mention that the second author of this paper participates in the project "EMagic," on which our research is based.

\section{CONCEPTUAL FRAMEWORK}

The experiments described in this paper are based on an articulated conceptual framework. Indeed, we have taken into account some decades of a vast literature on the use of serious games in mathematics education without going into the details of the applications in other disciplines (see Section Serious Games in Mathematics Education). The use of serious games in mathematics education can be traced back to the concept of instrumental genesis developed by Rabardel (see Section Instrumental Genesis). We describe how the integration of Pedagogical Knowledge (P.K.), Technological Knowledge (T.K.), and Content Knowledge (C.K.) is possible, describing the framework of Technological Pedagogical Content Knowledge (T.P.C.K.) (see Section Using Technology as a Learning Tool), and finally, in Section Research Questions research questions are addressed.

\section{Serious Games in Mathematics Education}

Serious games are games designed for a goal different from pure entertainment (Bellotti et al., 2010; Prensky, 2003; Zyda, 2005). They are receiving growing interest in education (De Grove et al., 2010). Exploiting the latest simulation and visualization technologies, serious games can contextualize the player's experience in challenging realistic environments, i.e., situated cognition (Van Eck, 2006). In this article, we will restrict ourselves to pointing out that the purpose of introducing serious games in mathematics lessons has been purely educational and not for entertainment. We aim to develop skills and competencies to be applied in the real world through exercising in a simulated and protected environment, namely a Serious game, despite being the Serious Game, a game to all intents and purposes. The design and use of serious games have a specific theoretical foundation in the constructivist learning theories that stress that knowledge is created through experience while exploring the world and performing activities (e.g., Dewey, 1933; Kolb, 1984). Implications on game design involve creating virtual environments, typically 3D, where the player can gain knowledge through exploration and practice (e.g., manipulating objects), possibly collaborating with other people. Constructivism stresses the learner's importance in building his or her knowledge. However, there is no unified theory on Serious Games pedagogy. Indeed, in the past, games were based on behavioral psychology. Today experiential learning has taken on particular importance, starting from the assumption that information and sensations experienced remain strongly imprinted and allow the player to refine perception, attention, and memory by favoring behavioral changes through learning (Arnab et al., 2012). The serious game player has the advantage of acting in a protected environment. Therefore, interacting with something that has been done in person is much easier than learning content conveyed during frontal lessons, so-called "passive learning". Making the simulation very close to reality reduces the new's fear by increasing the user's confidence in getting involved and improving the practical experience. The game element increases the involvement and allows to act more spontaneously, without feeling judged. The possibility to repeat the exercise countless times allows reaching the total mastery of the "explored" dynamics, increasing the serenity with which the instrument is used and with which the real situation will be faced. Many experiments have been carried out in mathematics education to analyze the enhancement of mathematical skills through serious games. For instance, Helena Campos and Rute Moreira (Campos \& Moreira, 2016) carried out an experiment using the game 'Caminhando e Calculando' (Moving and Calculating) to analyze the potential of the game as an educational resource for teaching and learning mathematics. Moreover, Ferrarello, Mammana, Pennisi, Taranto, and Turrisi (Ferrarello et al., 2019) focused on serious games for teaching and learning mathematics, highlighting how the method of horizontal teaching is effective in enabling students to achieve the learning objectives set by the teacher, designing and experimenting the serious game "FunGo", on the way of the pedagogical principle of "learning by playing" (Ferrarello et al., 2019).

When analyzed from the developers' point of view, implementing the serious game follows a well-known literature process. It is attributable to the use of agile methodologies for incremental software development. It is a well-proven and well-known process of software engineering. On the other hand, from the point of view of mathematical education, constructing the meaning that the game can assume in developing students' cognitive skills has certain originality. That derives from 
the interweaving of the aspects that link the serious game's engineering implementation to building mathematical knowledge.

For this experimentation, the extensive literature on serious games, illustrated in the introduction, was taken into account, and the more specific literature within mathematics teaching. Starting from those experiments' suggestions, this work's originality consists of the fact that a game has not been taken and tested in class. It has been designed, revised, and improved by analyzing the students' requests and suggestions and the teachers' contribution. So, we propose to show how the game genesis took place in a very gradual way, not by investigating the components of a pre-packaged artifact but by constructing the artifact itself. Recently, a systematic review of the use of serious games in science education has been carried out by Kara (2021). This review study's main objective was to reveal recent research trends on the use of serious games in science education. Based on the findings, several research suggestions are offered. In the paper, the author suggested that games should be increased to see the use and design issues of different genres of serious games in science education.

\section{Instrumental Genesis}

We refer to Rabardel's (1995) ideas on the intentional use of artifacts in teaching. Rabardel theorizes the concept of an instrumental approach underlining the difference between artifact and instrument: the first one is the material or symbolic object by itself (or a part of a composite artifact); the second one is defining it as a mixed entity "made up of both artifact-type components and schematic components that we call utilization schemes. This hybrid entity is born of both the subject and the object. This entity constitutes the instrument which has a functional value for the subject" (Rabardel \& Samurçay, 2001). An object is an artifact until some utilization schemes will be given. Therefore, there is an instrumental genesis (genèse instrumentale, Rabardel, 1995, p. 135 ff.) in which two complementary subprocesses can be distinguished: the "instrumentation", oriented by the artifact towards the subject, engaged in learning socially through shared utilization schemes and the "instrumentalization" with which the issue towards the artifact instructs the activity. The artifact's choice is significant to produce mathematical signs, and the teacher has a fundamental role in contributing to this. Indeed, a strict connection may be established between the artifact itself, the mathematical meanings that emerge from its use, and the mathematical meanings that arise from the discussion mediated by an expert. Here we study a serious game as an instrument consisting of:

- An artifact with a structure of both symbolic and material game elements has been used to create a game for a mathematics activity. These elements are the avatars, the levels, the badges, the scores; regarding deeper levels of game design, time constraints, limited resources, clear goals, obstacles, feedback, collaboration. The artifact also includes an accessory set as hardware and software, paper, etc.

- Cognitive schemes: they are the participants' schemes to use the serious game. For example, participants may end up "using" or "playing" a gamified application (Deterding et al., 2011).

Thus, in this paper, we consider serious game learning as a process of framing a non-game activity as a game, using the instrument design and adaptation in real situations of activity and play.

Generally, the teacher can choose the artifact and guide the instrumental genesis through which the students construct the mathematical meanings. In this experimentation, the Clash of Wizardry game was built following students' preferences and teachers' indications about the mathematical contents. We think that these two aspects have favored the instrumental genesis, and it has helped to favor the reorganization of cognitive structures of the student who called to compare, select, combine individual schemes and socially shared schemes.

\section{Using Technology as a Learning Tool}

The teacher's role is fundamental in guiding the instrumental genesis and helping students construct mathematical meanings (Capone et al., 2018). For this reason, in this experimentation, many complex aspects related to the use of technologies in teaching were taken into account.

With the recent success of technologies, a natural question is how Pedagogical Knowledge, Technological Knowledge, and Content Knowledge can be integrated. In 1986, Shulman introduced pedagogical content knowledge that includes pedagogical knowledge and content knowledge, among other categories (Shulman, 1986). In 2001, Pierson added the technological content to these categories. He illustrated the T.P.C.K. model as the intersection of three sets representing three knowledge domains: Technological Knowledge, Pedagogical Knowledge, and Content Knowledge (Pierson, 2001).

Gess-Newsome (1999) refers to an integrative model and a transformative model. The transformative model is analogous to a chemical compound, which resists easy separation of its components. Gess-Newsome describes it as "being inextricably combined into a new form of knowledge." The integrative model is analogous to a chemical mixture as components retain their identities, but they are indistinguishable on a macroscopic level; the teacher selects knowledge from three domains combining them as necessary to teach. Mishra \& Koehler 


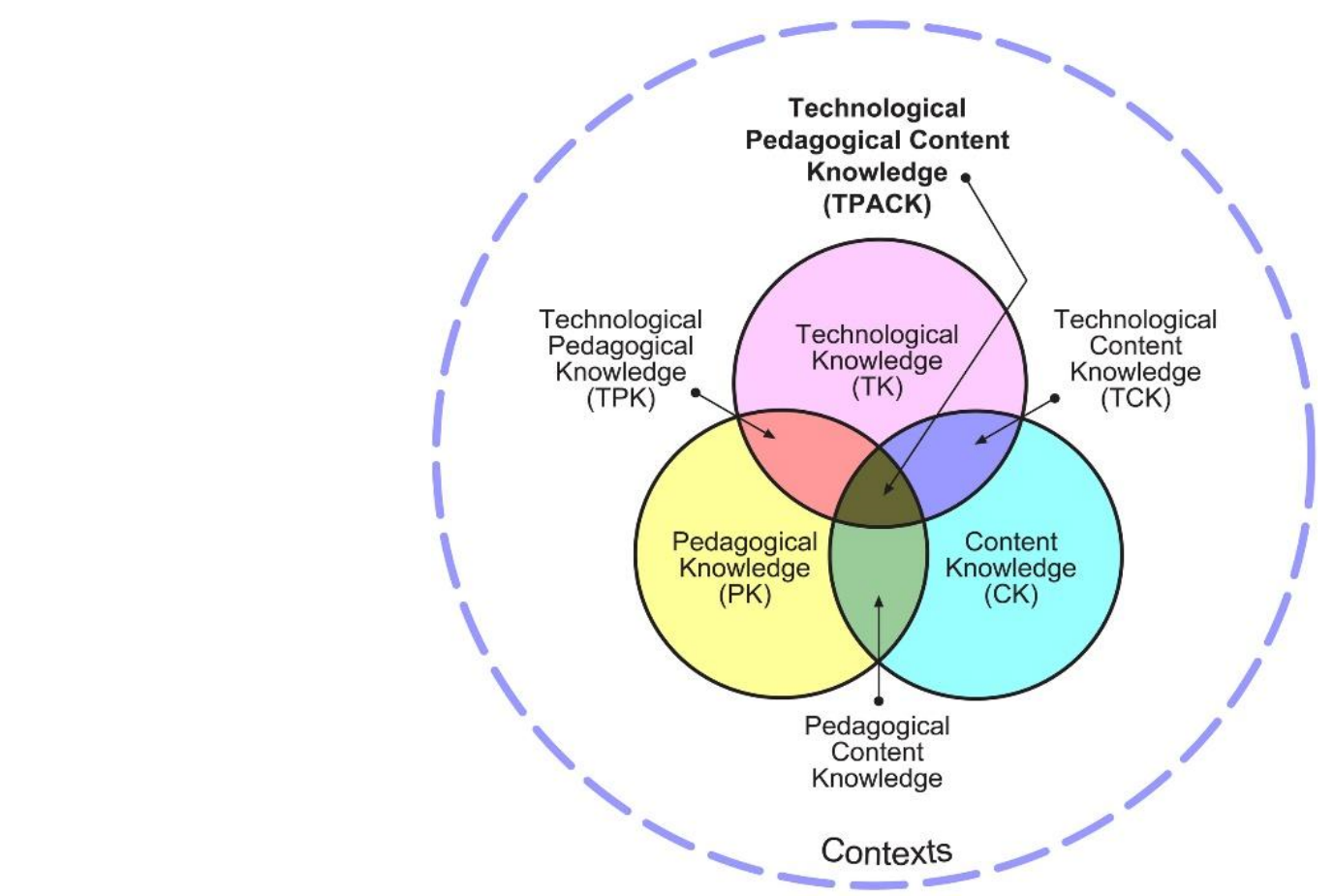

Figure 1. T.P.A.C.K. Venn diagram

(2006) describe the intersection between T.K. and C.K., P.K. and C.K., T.K. and P.K., they clarify the meaning of the intersections between Technology, Pedagogy, Content, and Knowledge, as Figure 1 shows.

They state: "Pedagogical content knowledge (P.C.K.) is concerned with the structure, organization, management, and teaching strategies for how the particular subject matter is taught. Technological content knowledge (T.C.K.) is related to how a particular subject matter is represented in technology-rich environments. Teaching with technology requires knowing the subject and how subject matter can be changed with technology application, and this knowledge is called T.C.K. Technological pedagogical knowledge (T.P.K.) is concerned with teaching and learning change due to integrating technology into instruction and choosing a particular tool for a particular task considering its affordances and limitations. Technological Pedagogical Content Knowledge (T.P.A.C.K.) is an emergent form of knowledge beyond all three components (p. 1028). According to transformative models, T.P.A.C.K. is different from knowledge of a disciplinary or technology expert and also from the general pedagogical knowledge shared by teachers across disciplines (p. 1029)". This model helps to read some results born and developed from the collaboration of different actors of the educational scene: teachers, researchers, and I.T. developers, as highlighted in a recent article on Dynamic Geometry System (Ferrarello et al., 2017). It helps us interpret the teachers' attitude towards innovation in teaching by inserting serious games into classroom practices. Indeed, teachers face a difficult challenge: They must integrate the knowledge of pedagogical contents, knowledge of teaching process, knowledge of technological contents that refers to how technology can create new representations for specific content, technological pedagogical knowledge that refers to various technologies used in teaching.

Recent studies aimed to develop and validate a T.P.A.C.K. scale to investigate mathematics teachers' knowledge levels in T.P.A.C.K. components, whether the mathematics teachers' T.P.A.C.K. levels differed in terms of gender, teaching experience, and school level, with a particular focus on primary and secondary mathematics teaching (Ozudogru \& Ozudogru, 2019).

Thus, the artifact undergoes a triple process of instrumental genesis: from a didactic point of view, because its use is aimed at generating knowledge and enhancing skills; from a pedagogical point of view, because its use is subordinated to appropriate teaching methodologies and aimed at the construction of mathematical meanings; and finally from a technological point of view because the use of serious games is not an end in itself, but it implements strategies for learning.

\section{Research Questions}

According to the T.P.A.C.K. model, researchers study the integration process between Pedagogical Knowledge, Technological Knowledge, and Content Knowledge, using serious games in the educational practice, setting the following items as a goal:

- Promoting the learning of mathematics as the acquisition of mathematical skills.

- Promoting a better students' emotional disposition towards mathematics through an educational action from informal learning into a contextualized and formal education. 

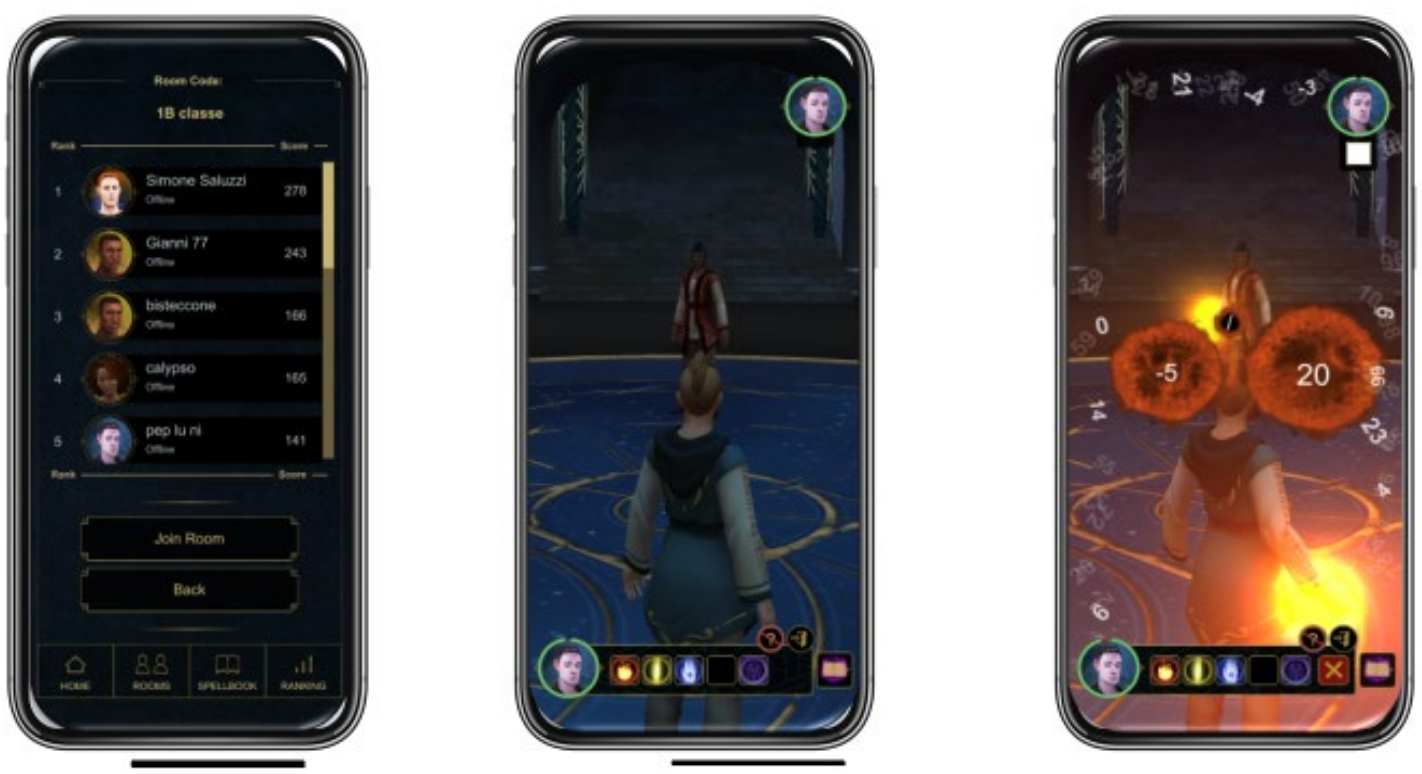

Figure 2. Clash of Wizardry - Game Screenshot

- Evaluating the positive impact of a serious game.

According to Rabardel, during the educational process, an instrumental genesis allows one to see the game as a playful object and educational purposes, useful to understand mathematics concepts better and acquire more skills in performing calculations.

Translated into the following research questions, these goals become:

- Can serious games encourage better emotional dispositions towards mathematics and improve the teaching-learning process of the discipline?

- Does the use of serious games allow the teacher to reflect on his teaching methodologies to encourage effective mathematics teaching?

The following description of the project activities tries to shed light on these questions and give plausible answers through a qualitative and quantitative analysis of the experimental data.

\section{PROJECT “E-MaGIC.”}

This section gives some information about the educational project "E-MaGIC."

The educational project "Education in Mathematics in Game-based Immersive contexts", called the acronym E-MaGIC, consists of digital games to learn mathematics. The challenge is to give teachers some sense of what a good video game should be for mathematics learning, and the challenge is to explain to game designers what it would take to embed good mathematics learning into a game. The project has a duration of 24 months and a supposed long-term legacy. It is part of the E.U. actions towards the diffusion of mathematics across Europe. Events have also taken place to disseminate the results, a website with downloadable materials has been realized. Finally, a handbook for teachers has been produced. It helps them use the game as a tool that can be integrated into their daily lessons. The app, named Clash of Wizardry, has been realized. It is a fast-paced game of magic duels in which one tries to win fame in the arena by casting spells quickly and mastering the most powerful spells. Spells are triggered by equalizing magic energies, which essentially means solving first-order linear equations. The purpose of the game is to achieve the calculation solution quickly.

One has success if one chooses the more challenging equations. One can focus on single duels, in training mode against a bot (offline), or against test opponents or other players, but one can also join a group and compete in a league-style contest. The way to winning the game is by selecting the right spells that deal maximum damage and are fast enough for you to cast. After all, duels are won by damaging your opponent faster and more than they can damage. In Clash of Wizardry, there are five spells: Darkness Embrace, Water Burst, Necromancy Touch, Fireball, and Blizzard. Each spell has three difficulty levels, the choice of the spell is free, higher-level spells do more damage but are also harder to cast. Simple spells only require simple math. However, powerful spells that give players an advantage require more difficult math concepts. Players can meet the avatars of friends in the arena and duel them using various magic spells. Casting a spell requires solving an equation or putting together or re-arranging a mathematical formula. To match against players who are on a similar skill level, it is possible to measure skill level with ranking points. This process is animated. It gives the appearance of weaving mysterious magic and provides the learner with the feeling of playing instead of working on a math problem. 
Table 1. Participants

\begin{tabular}{|c|c|c|c|}
\hline Country & Number & Gender & Age \\
\hline $\begin{array}{l}\text { "Acharnes Special Education } \\
\text { Vocational School" in Athens } \\
\text { (Greece), }\end{array}$ & $\begin{array}{l}70 \text { special } \\
\text { education } \\
\text { students } \\
\text { participated }\end{array}$ & $\begin{array}{l}19 \text { students are female } \\
(27.15 \%) . \\
51 \text { students are male } \\
(72.85 \%)\end{array}$ & $\begin{array}{l}10 \text { students aged } 12-13(14,28 \%), \\
24 \text { students aged } 14-15(34,28 \%), \\
29 \text { students aged } 16-17(41,42 \%), \\
7 \text { students aged } 18-20(10 \%) .\end{array}$ \\
\hline Madeira (Portugal) & $\begin{array}{l}222 \text { students } \\
\text { participated } \\
\text { in fifteen } \\
\text { classes }\end{array}$ & $\begin{array}{l}105 \text { male students }(46 \%) \text {, } \\
107 \text { female students } \\
(48 \%) \text {, and } 10 \text { students } \\
\text { (5\%) who didn't want to } \\
\text { specify their gender. }\end{array}$ & $\begin{array}{l}\text { from the } 7 \text { th grade ( } 70 \text { students), } \\
\text { from the } 8 \text { th grade ( } 48 \text { students); } \\
\text { from the } 9 \text { th grade ( } 66 \text { students), } \\
1 \text { VET class ( } 14 \text { students) } \\
\text { from the } 10 \text { th grade ( } 24 \text { students). }\end{array}$ \\
\hline $\begin{array}{l}\text { IIS “L. Da Vinci-Nitti”, a high } \\
\text { school in Potenza (Italy), }\end{array}$ & $\begin{array}{l}140 \text { students } \\
\text { participated }\end{array}$ & $\begin{array}{l}50 \text { of them are female and } \\
90 \text { males }\end{array}$ & $\begin{array}{l}43 \text { students aged } 14-15 \\
73 \text { students aged } 16-17 \\
24 \text { students aged } 18-20\end{array}$ \\
\hline
\end{tabular}

This game could be a helpful remedy to the general students' disaffection to the study of mathematics. Moreover, it can be modulated at different levels to suit other schools' students.

\section{Participants}

Our sample is randomly selected from the schools participating in this project. More precisely, the students are from Athens (Greece), Madeira Islands (Portugal), and the province of Potenza (Italy), as shown in Table 1.

The methodology for collecting experimental data was divided into three phases and covered several aspects. Regarding the verification of a possible improvement of skills, it should be emphasized that in Potenza, the students were divided into two groups. The teachers asked the first group to use the game as a useful tool to train their skills. The game was included in the didactic activities' planning; the second group was left free to use the game without teachers' solicitations. Both groups took an initial test on December 17th, 2019, and a final test on May 17th, 2020. The two tests concerned mathematical skills related to algebra, and they were Standardized National Tests (True/False, Multiple Choice, and Open-ended Questions). Other qualitative data were collected through an unstructured interview with the teachers who experienced the game in their classes.

\section{CLASH OF WIZARDRY INSTRUMENTAL GENESIS}

The implementation of the serious game required a reasonably long and complex process. This process can be analyzed from two points of view. The first point of view is that of developers, and the second is that of researchers in mathematics teaching. The software development steps are intertwined with the instrumental genesis phases that lead the student to use an artifact as a cognitive tool. Scheme 1 shows the fundamental stages of serious game development, divided according to 3 Intellectual Outputs. Each output is linked to the main activities conducted by the developers.

So, the game Clash of Wizardry development was divided into three steps, as we can see in the scheme. Three outputs are linked instrumental genesis steps shown in Scheme 2.

Firstly, the context has been studied. In particular, the following aspects were analyzed:

- Analysis of national curricula, and the game compatibility with the learning objectives of mathematics, i.e., how educators could integrate serious games into their classrooms.

- Research on educational applications of serious games in mathematics, especially in Europe, and the impact of their use in the classroom environment.

- Research on mathematics teaching methods to understand how to integrate informal learning with a more formal approach.

- Research about the student interest in games to develop a pleasant, easy, helpful app and motivate students to learn.

At the end of the first phase, we wrote a data report. Then we experimented with this game in the classroom. In this second phase, we gathered students' and teachers' feedback to remodel the game and make necessary changes, taking into account both the didactic aspects of game-based learning (teachers' feedback) and playfulness as a motivational tool (students' feedback). The following aspects of the game have been defined:

- Development of the game mechanics, i.e., the games' rules, the challenges, the effective way to motivate players.

- Development of graphics, animations, audio design.

- Game Usability testing to improve the game if necessary.

At the end of the second phase, the developers developed the app and presented it in the App Store. At the last stage, we focused our work on helping teachers 


\section{O1. Concept for immersive serious games in mathematics}

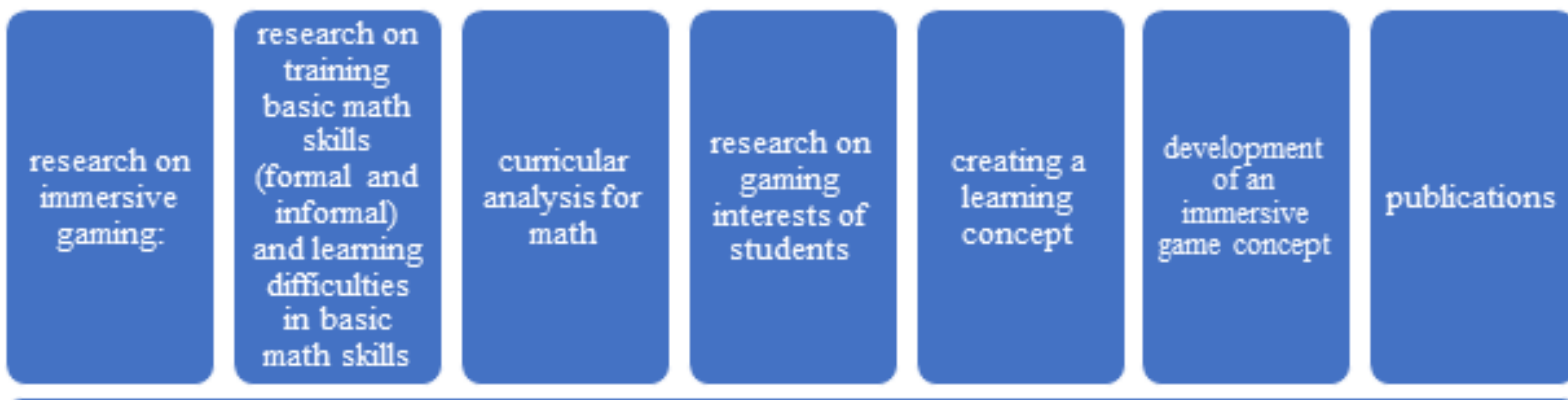

\section{O2. Serious game app for mobile devices}

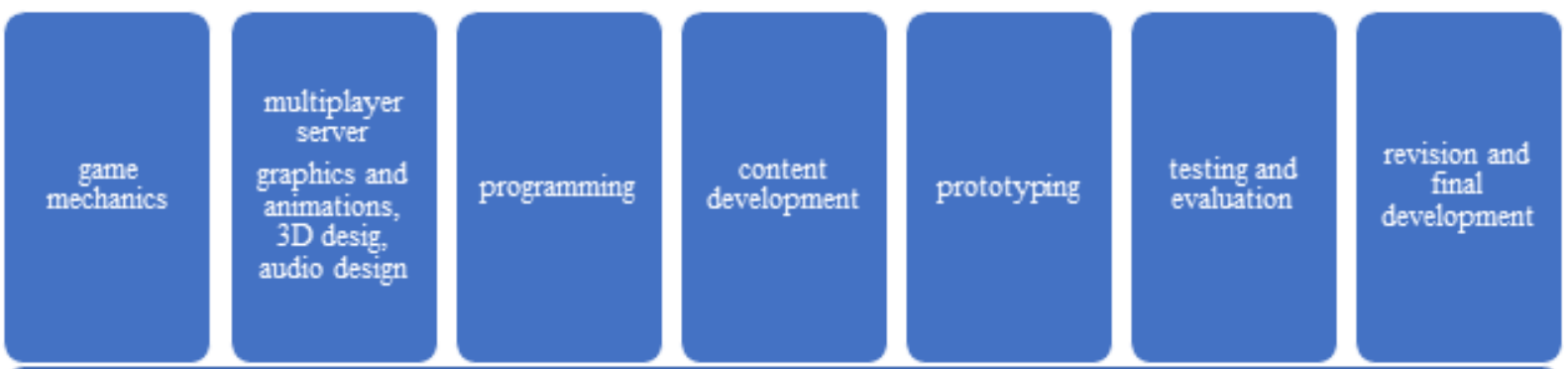

O3.Teacher Training and Materials
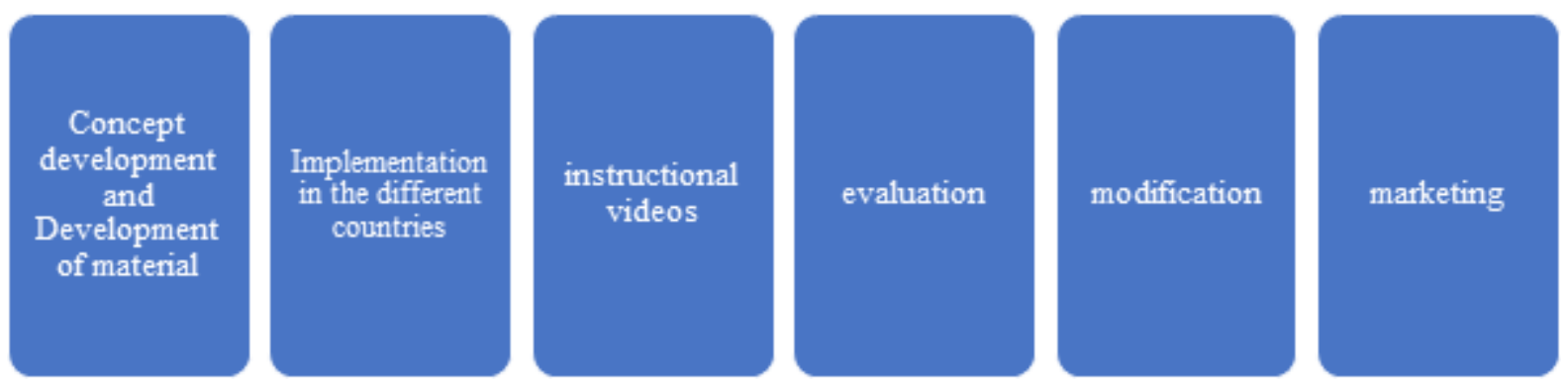

Scheme 1. Outputs
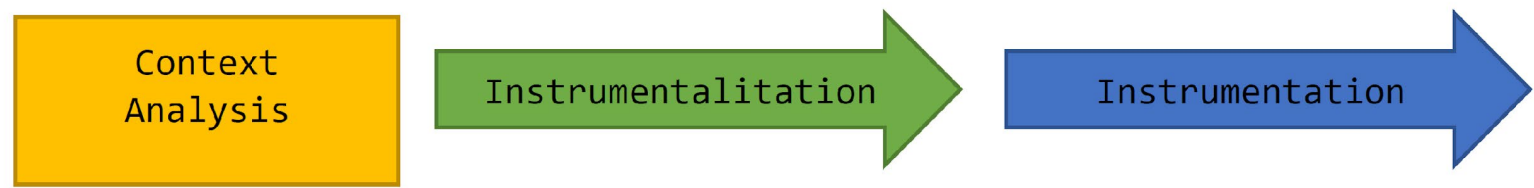

Scheme 2. Instrumental genesis

adapt the game's educational aspects and the game, impacting mathematical skills acquisition. According to the T.P.A.C.K. framework, we asked ourselves which elements were necessary from the three domains of knowledge to use an educationally effective product: concerning Technological Knowledge, the teachers had to acquire the necessary technological knowledge to allow their students to use the serious game in the classroom; concerning Pedagogical Knowledge, the teachers had to adapt an active methodology, outside the routine schemes of transmission teaching, to use the serious game with their students; concerning Content Knowledge, the teachers remodeled the didactic planning trying to adapt the serious game to make their students acquire disciplinary skills related to the solution of the first degree equations. 
A table links Clash of Wizardry elements to the disciplinary contents (Appendix). One can notice that there are three difficulty levels of the game.

According to Rabardel's instrumental genesis, referring to this specific activity, during the first step of the educational path, "instrumentation" processes are prevalent because the students are engaged in identifying game schemes. During the second phase, the processes of "instrumentalization" are prevalent because it is necessary to modify the artifact to improve its performance. During instrumental genesis processes, the student takes possession of patterns of use and enriches the artifact with new functions.

\section{EXPERIMENT DESIGN AND PROCEDURE}

This section is devoted to experimentation and procedure. First, we describe the adopted methodology, and then, in the following two subsections, we will describe the two phases of our experiment made in the partner countries.

Teachers have been involved in making the app's experience to be tested in their classes. The activity was carried out in 3 steps:

step 1. Control test before the introduction of the game.

step 2. Using the game in a formal learning context.

step 3. Control test after the introduction of the game.

This embedded case study's adopted methodology aims to include a specific educational situation and consider its uniqueness and specificity. The intentions were both idiographic, mainly using quantitative data collection techniques and nomothetic with a qualitative investigation. To analyze the didactic fallout of the experimentation, satisfaction questionnaires were administered to all educational process actors. The students' mathematical competencies were monitored by an initial and a final test. The analyzed factors by documents distributed to the teachers are:

- participation of students in the educational dialogue;

- student performances in math;

- involvement in the educational discussion of weak students;

- the usefulness of serious games in educational practices.

The factors analyzed testing the students are:

- improvement of the mathematical abilities;

- improvement of motivation to study mathematics.

The required skills are both specialized and citizenship skills. The specialized skills are as follows:
- using the techniques and procedures of arithmetic and algebraic calculation by representing them in graphic form;

- identifying appropriate strategies for problemsolving.

The citizenship skills are as follows:

- communication;

- identifying links and relationships;

- problem-solving;

- collaborating and participating.

The analyzed skills are as follows:

- the student can use the procedure to calculate arithmetic expressions and solve problems.

- The student can solve the first-degree equations and verify the functional procedures' correctness; he/she understands the concept of an equation.

\section{Experimentation in Madeira, Athens, and province of Potenza: Second Step Scoring}

In this subsection, data of the second test step of the game are listed and analyzed; these data contain the students' self-report ratings on how much they liked the game, and they have been used to review some game utilities as the set design and score.

The second test stage of the game Clash of Wizardry took place in the school EB 2,3 dos Louros from April 24 to May 9, 2019, with the same sample of students: 222 students, performed in fifteen classes: six from the 7 th grade (70 students), three from the 8 th grade (48 students); four from the 9th grade (66 students), one V.E.T. class ( 14 students) and one from the 10 th grade ( 24 students). The data sample consisted of 105 male students $(46 \%), 107$ female students $(48 \%)$, and ten students $(5 \%)$ who didn't want to specify their gender. Regarding the variable "age", the majority of the sample is between 14 and 15 years old (56\%), then $20 \%$ are between 12 and 13 years old, $21 \%$ are between 16 and 17 years old; $2 \%$ are between 18 and 20 years old and, finally, $0,5 \%$ are more aged than 20 years old (one student). The second test stage was implemented through direct observation in math classes of 45 minutes. The project team from G.M.T.E. briefed each class about the game's new version. G.M.T.E. provided smartphones which were distributed to each one of the students who had the opportunity to freely explore and play the game in training mode or duels mode (online matchmaking) in a game room. The G.M.T.E. team verified that students had fewer usability difficulties when playing Clash of Wizardry than in the first test stage. The student's motivation and the commitment to solve the calculations pointed to highlight throughout the game's exploration, although the students feel difficulty solving the calculations. From our point of view, one more time, the game was successfully accepted with excitement and motivation by the 
students, who afterward acknowledged the need for some time to train by themselves, so they could play more quickly and have better achievements in the game. Our students were involved in the testing activity, showing persistent and persevering behavior when exploring the game, although there were moments when they felt frustrated due to solving the calculations. Since one of the partners was a school in Greece, attended by students with special educational needs, the inclusive aspects of learning have been taken into account in the design and usability of the game "Clash of Wizardry". Indeed, focusing on disabilities, such as the memory of perception, cognition, communication, we tried to create an innovative and technologically advanced educational product that facilitates learning processes. These four factors have been taken into account: learning support that focuses on improving learning; accessibility, through the readability, predictability, and operability of the actions; usability, to make hardware and software technology simple to use; agency, i.e., the ability that makes the user an active part of learning.

The second test phase of the educational mobile game "Clash of Wizardry" took place in the greek school between the 13th to 23rd of May 2019. Seventy special education students from the school participated in the project. 51 students were male $(72,85 \%)$ while 19 students were female $(27,15 \%)$. Ten students were in the age of $12-13(14,28 \%), 24$ students were in the age of 14 $15(34,28 \%), 29$ students were in the age of $16-17$ $(41,42 \%)$, and seven students were in the age 18-20 (10\%). Students were introduced to the mathematics teachers' new game features and then played the game for two 30 minutes sessions. After the end of the sessions, a survey was handed to them to express their opinion in several questions. The general impression was that students welcomed the new version of the game with great enthusiasm and played the game within a flow state.

The second experimentation of "Clash of Wizardry" was performed at IIS "Da Vinci-Nitti", in Potenza and Brienza (a little town near Potenza). The classes involved were 10 . The students who experimented with the game in their classes were divided into small groups by testing the various game modes such as training, challenging each other in duels, or organizing in rooms for about an hour at different times. They were guided and monitored by the school's project team teachers, who told them how to download the game to their smartphones at home before the test. After the sections test, their teachers had the task of explaining the innovations made to the game to the students for the correct use of it. It was also explained to them that the second version of the game was more complete than the previous one, not only because it presented the possibility of experimenting with the various game modes, checking the score obtained immediately, but also for the use of the spells that had passed from the initial 4 to 8 (equivalent to more challenging math levels) with increasingly powerful effects.

Moreover, the teachers said that the graphics and other technical aspects of the game improved. The test emerged that the students, who had already tested the first version of the game, were satisfied with the improvements. The main results of the survey can be summarized as follows:

- For $70 \%$ of the students, the game was easy to play. They liked the different technical aspects of the game, such as sound, graphics, game modes, and customization of the avatar;

- $70 \%$ of students liked the new version of the game, and more than $50 \%$ of them would like to download it permanently on their device.

- $80 \%$ of students considered the game's level and the match's duration to be appropriate, while more than $68 \%$ would recommend it to a friend.

These percentages can be checked in the "official common excel document of the Second test stage survey".

In this second phase of experimentation, in instrumental genesis, instrumentalization prevailed: In fact, the artifact's cognitive potential has been refined thanks to the students 'and teachers' suggestions after the game experimenting. Furthermore, thanks to the experiments in the classroom, the signs, which emerge from the activity carried out with the use of a tool, have been elaborated under the guidance of the teacher who has the task of guiding his students in the elaboration of these signs and their interpretation in the form of mathematical knowledge.

The gamification artifact helped to shape the revision work into a learning situation (See Table 2).

\section{Experimentation in the Province of Potenza (Italy): Third Step Scoring}

This subsection briefly describes the third phase of the experimentation that helped us analyze which mathematical skills students have acquired through gamification activities and analyze students' satisfaction. From the satisfaction test, it is possible to consider the students' motivation to study mathematics.

In this third step, 142 students from the Potenza province were involved: more precisely, 96 of them from Potenza and Brienza. We give them two tests: the first was made on December 17th, 2019, and the second was made on May 17th, 2020. The tests were taken from "I.N.V.A.L.S.I." ("Italian National Institute for the Evaluation of the Education and Training System" section Numbers). Indeed, among the four possibilities into which the I.N.V.A.L.S.I. tests are divided (Numbers, Spaces and Figures, Data and Forecasts, Relations and Functions), "Numbers" has been selected. We compare the results before and after using the app in the 
Table 2. Instrumentalization and instrumentation

\begin{tabular}{|c|c|c|}
\hline & Gameplay & The link between game and activity \\
\hline $\begin{array}{l}\text { Instrumentalization (artifact } \\
\text { change): } \\
\text { The game layers. } \\
\text { The accessory set }\end{array}$ & $\begin{array}{l}\text { Firstly, the game was designed to } \\
\text { compete against a fake avatar, and } \\
\text { then the social aspect was valued } \\
\text { by allowing players to compete } \\
\text { with each other. }\end{array}$ & $\begin{array}{l}\text { The students argued that the game, in the first } \\
\text { version, was boring because there was little } \\
\text { competition. This has prompted developers to } \\
\text { network the game to compete with their peers and } \\
\text { create class tournaments within their schools and } \\
\text { even between partner schools. }\end{array}$ \\
\hline $\begin{array}{l}\text { Instrumentation } \\
\text { (user scheme adjustment) }\end{array}$ & $\begin{array}{l}\text { At first, the game was not well } \\
\text { structured on the students' } \\
\text { specific mathematical skills. }\end{array}$ & $\begin{array}{l}\text { The teachers helped the developers calibrate the } \\
\text { math questions' difficulty based on the different } \\
\text { types of equations and the scores assigned. }\end{array}$ \\
\hline
\end{tabular}

D11. Nel risolvere l'equazione scritta alla riga 1, è stato commesso un errore.

$$
\begin{aligned}
& -10 x-2+4 x-4=0 \\
& -10 x+4 x=2+4 \\
& 6 x=6 \\
& x=\frac{6}{6} \\
& x=1 \\
& \text { In quale passaggio è stato commesso l'errore? } \\
& \square \quad \text { A. Nel passaggio dalla riga } 1 \text { alla riga } 2 . \\
& \square \quad \text { B. Nel passaggio dalla riga } 2 \text { alla riga } 3 . \\
& \square \quad \text { C. Nel passaggio dalla riga } 3 \text { alla riga } 4 . \\
& \square \quad \text { D. Nel passaggio dalla riga } 4 \text { alla riga } 5 .
\end{aligned}
$$

Figure 3. Invalsi Test 2009 - Grade 8 - Question 11

D16.

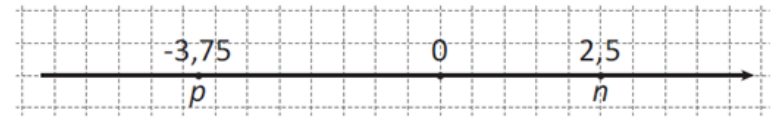

Se moltiplichi $n$ per un numero indicato con $k$ ottieni come risultato $p$.

$$
n \cdot k=p
$$

$$
\begin{aligned}
& \text { Qual è il valore di } k \text { ? } \\
& \begin{array}{l}
\text { A. } \square \\
\text { B. } \square+1,5 \\
\text { C. } \square-1,5 \\
\text { D. }-3,75 \\
\text { D. } \quad+1,25
\end{array}
\end{aligned}
$$

Figure 4. Invalsi Test 2016 - Grade 8 - Question 14

classroom. Here are two questions from the Invalsi tests. They are selected examples from ten questions given to the students. We offer first the original version in Italian and then the translated version (Figure 3 and 4). skills:

So, in particular, we test according to the following

1. the student knows, and she/he can use the positional (numeral) system,

2. the student is able to recognize different ways to write a number,
In solving the following equation, there is a mistake. Where?

$$
\begin{gathered}
-10 x-2+4 x-4=0(1) \\
-10 x+4 x=2+4(2) \\
6 x=6(3) \\
x=6 / 6(4) \\
x=1(5)
\end{gathered}
$$

Answer:
A. From line 1 to line 2
B. From line 2 to line 3
C. From line 3 to line 4
D. From line 4 to line 5 .

3. the students can identify relationships between quantities,

4. the student is able to solve the first-degree equations,

5. the student is able to know the previous mathematical objects, their structures, and properties.

In the end, we invited the students to express their opinion, and 50 of them answered. We sent them questionnaires via Google Forms. For scaling responses in the survey, we used the format of a typical five-level Likert item, as shown in Table 3. 
Table 3. Likert scales about statements of agreement, frequency, and satisfaction

\begin{tabular}{ccccc}
\hline Strongly Disagree & Disagree & Undecided & Agree & Strongly Agree \\
\hline Never & Rarely & Sometimes & Often & Always \\
Not at all Satisfied & Slightly satisfied & Moderately Satisfied & Very satisfied & Completely Satisfied \\
$(1)$ & $(2)$ & $(3)$ & $(4)$ & $(5)$ \\
\hline
\end{tabular}

\section{FINDINGS}

Here we collect the findings from our case study.

First, we stress that the educational project on the use of serious games for learning mathematics is part of a recent but consolidated research line regarding the use of serious games in teaching. However, our innovative contribution, compared to the existing literature, consists in the fact that the game has not been entrusted to teachers as a finished product and packaged for use; instead, it was built for students with the students and scientific support of researchers in mathematics education and with the didactic and methodological support of mathematics teachers. It seems to have produced significant results concerning the teachinglearning process's two aspects: it has influenced teachers' teaching action and sure students' beliefs.

From another point of view, the use of serious games in teaching practice led the teacher to rethink his teaching method because teachers were faced with the challenge of integrating knowledge of pedagogical contents, knowledge of the teaching process, and knowledge of technological contents. Following the T.P.A.C.K., they had to mediate these three aspects to make their lesson effective and to make the game a serious tool for learning mathematics by working in the conditions in which T.K., C.K., and P.K. meet.

In his essay "Things that make us smart"(1993), Norman uses the term "cognitive artifacts" to underline the role that every tool, both material and symbolic, can play in implementing the cognitive potential of those who make use. Furthermore, he distinguishes two fundamental thought processes: "experiential cognition" and "reflective cognition". The experiential modality involves an effortless appreciable immediate reaction to external stimuli; reflective thought processes lead to confrontation. Based on this distinction, this educational experiment on using serious games to improve mathematical skills was kept in mind that the game itself can be configured as "experiential cognition", that is, a simple automatism that does not contribute to broadening disciplinary knowledge of the students. However, if the teacher prepares, plans, and designs specific paths, he can induce "reflective thinking" processes. The teacher can promote the comparison of the solutions proposed by the students. The teacher can facilitate the emergence of use patterns.

According to the theory of instrumental genesis and T.P.A.C.K., the role of the teacher was essential to favor a triple process of instrumental genesis: from the didactic point of view, because its use is aimed at generating knowledge and enhancing skills; from a pedagogical point of view, because its use is subordinated to appropriate didactic methodologies and aimed at the construction of mathematical meanings; and finally from a technological point of view, because the use of serious games is not an end in itself, but it implements learning strategies. Therefore, concerning the research questions: Can serious games encourage better emotional dispositions towards mathematics and improve the discipline's teaching-learning process?

The students' answers to the questionnaire seem to confirm the students' positive attitude towards mathematics. Here are the answers to some questions. The first question was: "Do you like Clash of Wizardry?"

As we can see in Figure 5, most students like the game, whose implementation they collaborated on, and $21.2 \%$ liked it very much. The second question was: "Did Clash of Wizardry help you improve your mathematics results?"

As Figure 6 shows, most students $(76.9 \%)$ say that "Clash of Wizardry" helps the study of mathematics.

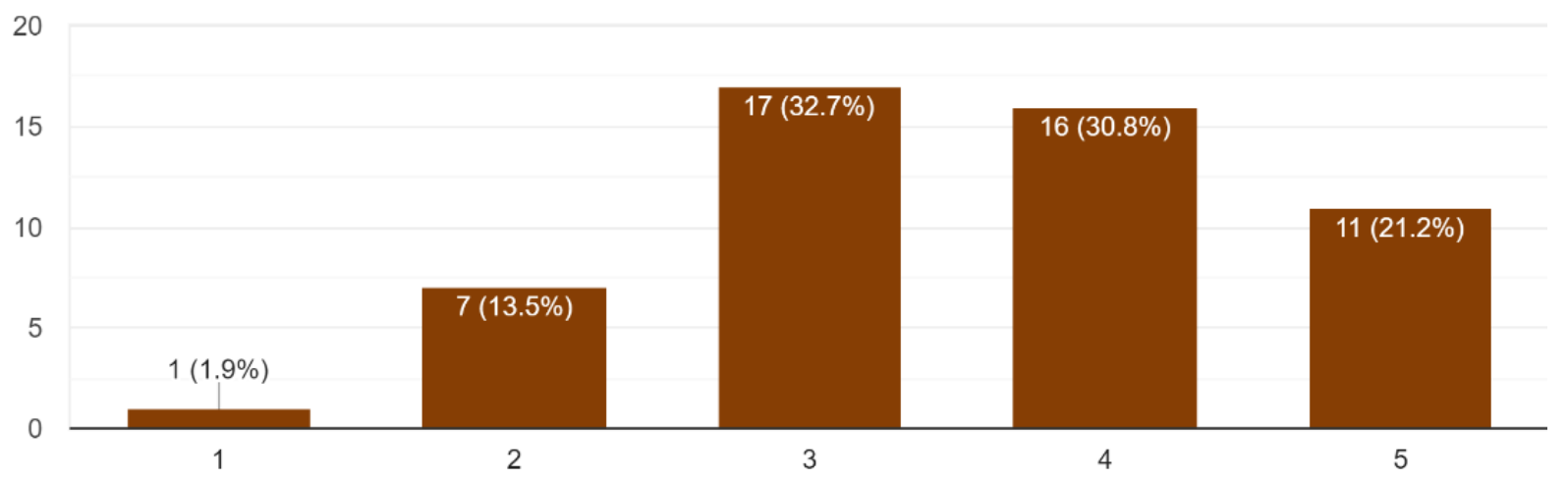

Figure 5. Student's answers to the question: "Do you like Clash of Wizardry?" 


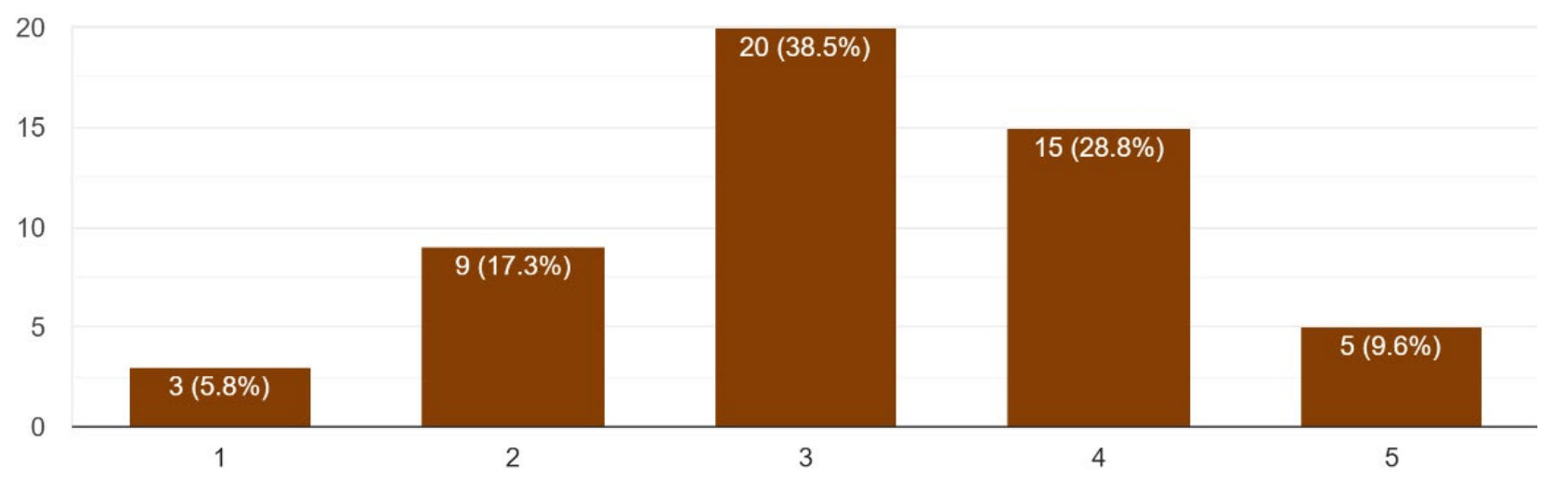

Figure 6. Student's answers to the question: "Did Clash of Wizardry help you to improve your results in Mathematics?"

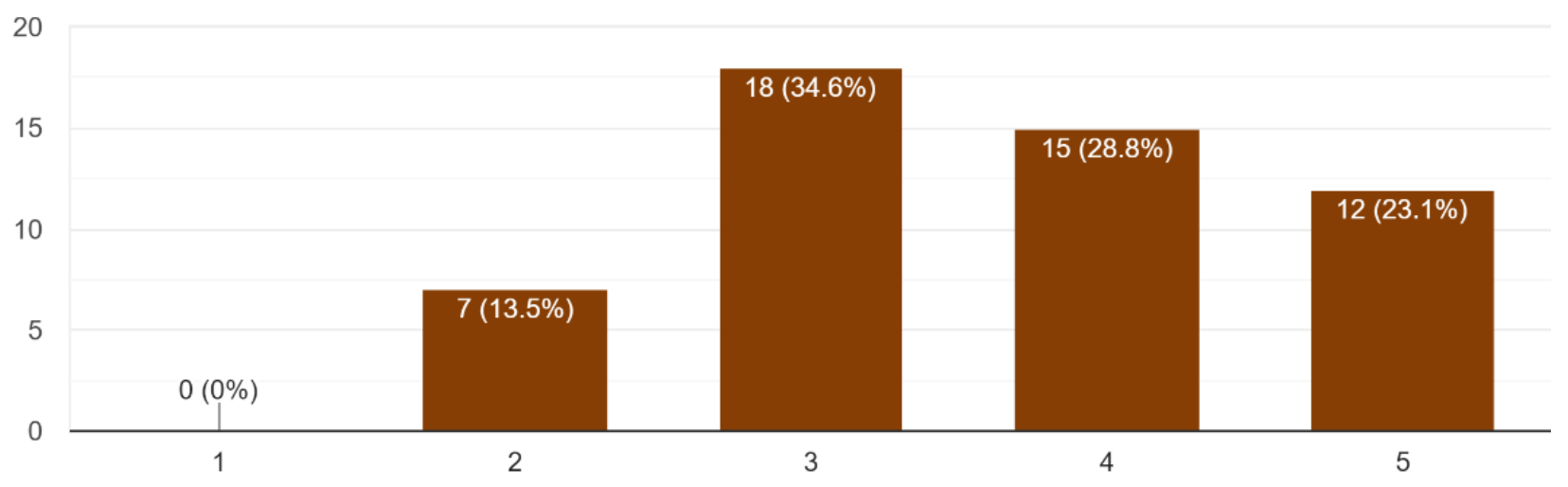

Figure 7. Student's answers to the question: "Would you like to use serious games for other topics?"

Then we asked: "How did it help you?" They wrote that it made them faster in calculations. They now face the study of mathematics with greater confidence; some reported that they did not think that it was possible to learn mathematics except through severity. Another question was: "Would you like to use serious games for other topics?"

Most of the student's answers (86.5\%) are located from 3 to 5 on the Likert scale, showing that they appreciated serious games so much that they wanted to repeat the experience on other topics. The last question was: "Write your opinion on Clash of Wizardry".

Here are some answers:

- Student 1's answer: "At the end, it came out a nice game, it was fun to play, and we learned to calculate faster without even realizing it."

- Student 2's answer: "It is not just about making calculations but also knowing how to choose the best strategy to defeat the opponent: this has prompted us to try our hand at increasingly complicated mathematical situations to win a challenge."

- Student 3's answer: "I started to get interested in mathematics, and I'm already thinking of some other game to study other subjects in this way."
Almost all of these students appreciate the game. They say that Clash of Wizardry is fun, very friendly, very intuitive, very effective. The game helps boost his/her Self-Esteem and improves his/her calculation skills.

The students' high approval also seems to be evident from the Likert scale questionnaire: $84.7 \%$ of students like the game, $21.2 \%$ like it very much. The most exciting answers come from students who liked math the least and had shown difficulty, while students who already had a high rating seem more indifferent to the game.

According to the data collected, $76.9 \%$ of students believe they have improved in mathematics. Again, the most exciting responses came from the students who scored below the pass, while for the students with a high rating, improvement was more limited.

Another empirical evidence of the experiment is that students seemed little attracted by the first version of the game. The added value of Clash of Wizardry seems to derive precisely from the fact that the game was built for students together with students. They were thus able to express their preferences on graphics, scores, progress from one level to the next. It seems that the game was tailor-made for the students. When asked, "Would you like to use serious games for other topics?", $86.5 \%$ of students replied that they would like to repeat the experience on 
other mathematical topics. It seems that the use of Clash of Wizardry has not only motivated the students but improved their math skills.

These data seem to be confirmed and strengthened by students' results in improving mathematical skills. They were comparing both the results of December and May, a marked improvement in the students of group $\mathrm{A}$ is underlined, where the game has been used, compared to group B, whose teachers have not encouraged the use of the game. More precisely, group B's average score went from 6.38 obtained in December 2019 to 5.61 in May 2020, while the average score obtained by group A went from 6.04 brought in December to 7.17 in May. This result is due not only thanks to the training of the mathematical skills by "Clash of Wizardry", but also and above all, thanks to teachers' different approach as they decide to modify their proposal teaching, getting closer to how children interact with others using network and social games.

In an unstructured interview, teachers stated that their students, as proved by tests carried out during the year, improved their mathematical skills. Above all, most of them showed more interest in the discipline study. In their opinion, students also achieved the following skills:

- using the techniques and procedures of arithmetic and algebraic calculation by representing them in graphic form.

- Identifying appropriate strategies for problemsolving.

Moreover, the teachers said that, after using the game, most of the students could calculate arithmetic expressions, solve the first-degree equations, verify the correctness of the procedures, and understand the concept of an equation.

Regarding the following research question: Does the use of serious games allow the teacher reflective action on their teaching methodologies to encourage effective teaching of mathematics?

Many teachers, initially perplexed about using serious games in the classroom, have already changed their minds after the first experimentation. Some teachers were skeptical of the prototype presented because, according to them, there was no relationship between the game and the mathematical skills that the students should have acquired. Subsequently, their contribution was decisive in modifying the game appropriately to adapt it to students' training needs. Thus, each spell's action in the game was matched by a well-defined equation, the resolution of which would have made the player acquire points: a more powerful spell corresponded to an equation of a more complex solution.

\section{CONCLUSION}

In this final section, we give the conclusions. Our embedded case study aims to describe the development, implementation, and experimentation of a serious game for educational purposes. It has become a didactic tool through a process of instrumental genesis as a simple artifact. This case study aims to analyze, on the one hand, the didactic-educational aspects of the game use in the classroom for learning mathematics, and therefore the researcher's attention is placed on the student: how he interacted with the game, how he helped to improve the game, how the instrumental genesis of the game took place concerning the student's attitudes, how the student's mathematical skills improved, how his predisposition towards the study of mathematics has changed. On the other hand, the attention of the research was placed on the teacher's attitude towards the use of innovative teaching methodologies mediated by the use of technology, as the initial skepticism towards the use of serious games has changed, how he had to integrate his disciplinary knowledge with computer and pedagogical skills.

The research project lasted for two years (2017-2019), was carried out within the Erasmus+ project and involved people from "Acharnes Special Education Vocational School" in Athens (Greece), IIS “L. Da VinciNitti", a high school in Potenza (Italy), and from Gabinete de Modernizao das Tecnologias Educativas (G.M.T.E.) in Madeira Islands (Portugal). The project aimed to involve students in learning mathematics by exploiting a video game's potential as an innovative learning tool. A new and innovative educational game for mobile devices has been developed within the project, namely Clash of Wizardry. This app is a fastpaced game of magic duels in which one tries to win fame in the arena by casting spells quickly and mastering the most powerful spells. Spells are triggered by equalizing magic energies, which essentially means solving first-order equations. The purpose of the game is to achieve the calculation solution quickly. One has success if one chooses the harder equations. One can focus on single duels, in training mode against a bot (offline), or against test opponents or other players, but one can also join a group and compete in a league-style contest.

The way to winning the game is by selecting the right spells that deal maximum damage and are fast enough for you to cast. After all, duels are won by damaging your opponent faster and more than they can damage. In order to investigate how the teachers and the students perceived the use of this app, they answered a questionnaire at the end of their experience. It is important to note that teachers want to test the app in their classrooms in the future. Teachers appeared satisfied with the utility's concerns, and students were confident about the app's enjoyability. Seventy-five 
percent of the teachers declared that the app is suitable for training math skills in class, 80 percent of the teachers said that the app is good for training math skills at home. Most of them declared that concentration is enhanced thanks to students' app. Most of them appreciate that students get socialized through playing with friends, and they also said that students who lose their focus quickly now get focused quicker and for more time while playing the game. They noticed that after practicing this game, the students make calculations faster.

Moreover, unlike what happened in control tests before using the app, students manifested frustration and rejection behaviors, teachers noticed a completely different attitude being more relaxed, motivated, and comfortable. The game dynamics contributed to analytical skills and memory development. Students showed commitment and dedication in their matches to achieve better results, not giving upon them. The availability of several spells with specific actions and characteristics (of attack, defense, or healing) contributed to developing skills like strategic thinking and decision making. Finally, the game reinforced cooperative behaviors among peers. From teachers' opinions, it seems that adapting the artifact has started: in a didactic, pedagogical and technological sense. The learner, therefore, was faced with a triple instrumental genesis of the game. T.P.A.C.K.'s theoretical model seems to confirm our hypothesis that this learning situation means both a pedagogical and technologically innovative contribution. So, we worked in the intersection of P.C T.C.K. and T.P.K.

The final test results, the questionnaire, and the teacher's interview seem to show that serious games encourage better emotional dispositions towards mathematics and improve the teaching-learning process of the discipline. Moreover, serious games seem to allow the teacher to reflect on his teaching methodologies to encourage effective mathematics teaching.

The possibility of trying this app in many classrooms gave us validation of our ideas.

Author contributions: All authors have sufficiently contributed to the study, and agreed with the results and conclusions.

Funding: No funding source is reported for this study.

Declaration of interest: No conflict of interest is declared by authors.

Acknowledgements: We thank the Department of Mathematics of the University of Salerno researchers who participated in the project. We also thank all the teachers at the schools who welcomed us in their classes for the experimental phases.

\section{REFERENCES}

Arnab, S., Berta, R., Earp, J., De Freitas, S., Popescu, M., Romero, M., Popescu, M., Stefan, I. A., \& Usart, M. (2012). Framing the adoption of serious games in formal education. Electronic Journal of e-Learning, 10(2), 159-171.
Barbieri, G., Barbieri, R., \& Capone, R. (2019). I serious games per una didattica della matematica inclusiva [Serious games for inclusive mathematics education]. Quaderni di Ricerca in Didattica, 2, 95-96.

Bellotti, F., Berta, R., \& De Gloria, A. (2010). Designing effective serious games: Opportunities and challenges for research. International Journal of Emerging Technologies in Learning, 5(SI3), 22-34. https:// doi.org/10.3991/ijet.v5s3.1500

Beutner, M., \& Pechuel, R. (2018). Game-based learning for teachers-A journey through a world of new ideas. Game on Consortium and Ingenious Knowledge $\mathrm{GmbH}$.

Brom, C., Sisler, V., \& Slavík, R. (2010). Implementing digital game-based learning in schools: augmented learning environment of 'Europe 2045'. Multimedia Systems, 16(1), 23-41. https://doi.org/10.1007/ s00530-009-0174-0

Campos, H., \& Moreira, R. (2016) Games as an educational resource in the teaching and learning of mathematics: an educational experiment in Portuguese middle schools, International Journal of Mathematical Education in Science and Technology, 47(3), 463-474. https:/ / doi.org/10.1080/0020739X. 2015.1075614

Capone, R., \& Lepore, M. (2020). Augmented Reality to Increase Interaction and Participation: A Case Study of Undergraduate Students in Mathematics Class. In International Conference on Augmented Reality, Virtual Reality and Computer Graphics (pp. 185-204). Springer. https:/ / doi.org/10.1007/978-3030-58468-9_15

Capone, R., Adesso, M. G., Del Regno, F., Lombardi, L., \& Tortoriello, F. S. (2020, 14 February). Mathematical competencies: A case study on semiotic systems and argumentation in an Italian High School. International Journal of Mathematical Education in Science and Technology, 1-16. https:/ / doi.org/10.1080/0020739X.2020.1726517

Capone, R., Del Regno, F., \& Tortoriello, F. (2018). ETeaching in mathematics education: The teacher's role in online discussion. Journal of e-Learning and Knowledge Society, 14(3), 41-51. https://doi.org/ 10.20368/1971-8829/1538

Chen J. (2007), Flow in games (and everything else). Communications of the AMC-Association for Computing Machinery, 50(4), 31-34. https:/ / doi.org /10.1145/1232743.1232769

Clark A. (2001). Mindware: An Introduction to the philosophy of cognitive science. Oxford University Press.

D'Amore, B., \& Fandino Pinilla, M. I. (2007) How the sense of mathematical objects changes when their semiotic representations undergo treatment and conversion. La matematica e la sua didattica (Bologna, Italy), 21(1), 87-92. 
De Grove, F., Van Looy, J., \& Courtois, C. (2010). Towards a serious game experience model: Validation, extension, and adaptation of the G.E.Q. for use in an educational context. In Playability and player experience (Vol. 10, pp. 47-61). Breda University of Applied Sciences.

Devlin, K., Kill, K., \& Multisilta, J. (2015). Editorial: Is game-based math learning finally coming of age? International Journal of Serious Games, 2(4), 1-4. https:/ / doi.org/10.17083/ijsg.v2i4.109

Dewey, J. (1933). How we think, a restatement of the relation of reflective thinking to the educative process (No. $370.15 \mathrm{D} 48)$.

Easley, D., \& Ghosh, A. (2016) Incentives, Gamification, and Game Theory: An Economic Approach to Badge Design. A.C.M. Transactions on Economics and Computation, 4(3), Article 16. https://doi.org/ $10.1145 / 2910575$

Ferrarello, D., Gallo, G., Lombardo, M., Mammana, M. F., Pennisi, M., Stanco, F., \& Viagrande, L. C. (2018). FunGo: un serious game per la matematica. A cura di: Marina Rui [FunGo: a serious math game. Curated by: Marina Rui]. In Proceedings della Multiconferenza EMEM ITALIA: Progress to work Contesti, processi educativi e mediazioni tecnologiche (pp. 425-432). Genova University Press.

Ferrarello, D., Mammana, M. F., \& Pennisi, M. (2014). Teaching by doing. Proceedings of C.I.E.A.E.M. 2013: Q.R.D.M., 24(1), 429-433.

Ferrarello, D., Mammana, M. F., Pennisi, M., \& Taranto, E. (2017). Teaching intriguing geometric loci with D.G.S. Aldon, G., Hitt, F. Bazzini, L., Gellert, U. (Eds.): Mathematics and Technology. A C.I.E.A.E.M. Sourcebook. Springer. https:/ / doi.org/10.1007/9783-319-51380-5_26

Ferrarello, D., Mammana, M. F., Pennisi, M., Taranto, E., \& Turrisi, A. (2019). Serious Games in Teaching/Learning Mathematics: The Experience of FunGo. In Proceedings of the 15th International Conference of the Mathematics Education for the Future Project Theory and Practice. https:/ / doi.org/10.37626/GA9783959871129.0.30

Forman, E. (1989). The role of peer interaction in the social construction of mathematical knowledge. International Journal of Educational Research, 13(1), 55-70. https://doi.org/10.1016/0883-0355(89) 90016-5

Gess-Newsome, J. (1999). Pedagogical content knowledge: An introduction and orientation. In Examining pedagogical content knowledge (pp. 3-17). Springer. $\quad$ https://doi.org/10.1007/0-306-472171_1
Kara, N. (2021). A Systematic Review of the Use of Serious Games in Science Education. Contemporary Educational Technology, 13(2), ep295. https://doi.org/10.30935/cedtech/9608

Kolb, B. (1984). Experiential learning: Experience as the source of learning and development. Prentice-Hall.

Matos, J. M. (2020). Construing Professional Knowledge of Secondary School Teachers of Mathematics: A Historical Perspective. Pedagogical Research, 5(3), em0058. https:/ / doi.org/10.29333/pr/7898

Mishra, P., \& Kohler, M. J. (2006). Technological pedagogical content knowledge: A framework for teacher knowledge. Teachers College Record, 8(6), 1017-1054. https://doi.org/10.1111/j.1467-9620. 2006.00684.x

Ozudogru, M., \& Ozudogru, F. (2019). Technological Pedagogical Content Knowledge of Mathematics Teachers and the Effect of Demographic Variables. Contemporary Educational Technology, 10(1), 1-24. https:/ / doi.org/10.30935/cet.512515

Pierson, M. E. (2001). Technology Integration Practice as a Function of Pedagogical Expertise. Journal of Research on Computing in Education, 33(4), 413-430. https: / / doi.org/10.1080/08886504.2001.10782325

Prensky, M. (2003). Digital game-based learning. A.C.M. Computers in Entertainment, 1(1). https:/ / doi.org/10.1145/950566.950596

Rabardel P. (1995). Les hommes et les technologies; approche cognitive des instruments contemporains [Men and technologies; cognitive approach to contemporary instruments]. Armand Colin.

Rabardel, P., \& Samurçay, R. (2001, March). From artifact to instrument-mediated learning. In Symposium on New challenges to research on learning (pp. 21-23).

Shaffer, D. W., \& Gee, J. P. (2005). Before every child is left behind: How epistemic games can solve the coming crisis in education. WCER Working Paper No. 2005-7.

Shulman, L. S. (1986). Those who understand: Knowledge growth in teaching. Educational researcher, 15(2), 4-14. https://doi.org/10.3102/ 0013189X015002004

Shute, V. J., Ventura, M., Bauer, M., \& Zapata-Rivera, D. (2009). Melding the Power of Serious Games and Embedded Assessment to Monitor and Foster Learning: Flow and Grow. In U. Ritterfeld, M. Cody, \& P. Vorderer (Eds.). Serious Games Mechanisms and Effects (pp. 295-321). Routledge.

Van Eck, R. (2006). Digital game-based learning: It's not just the digital natives who are restless. EDUCAUSE review, 41(2), 16.

Zyda, M. (2005). From visual simulation to virtual reality to games. Computer, 38(9), 25-32. https://doi.org/ 10.1109/MC.2005.297 


\section{APPENDIX}

\begin{tabular}{|c|c|c|c|c|c|}
\hline Equation & Spell Name & Category & Level 1 & Level 2 & Level 3 \\
\hline$a+x=b$ & $\begin{array}{l}\text { Darkness } \\
\text { Entrance }\end{array}$ & Darkness & $\begin{array}{l}\text { 1point of damage, } \\
\text { darkness } 2 \text { sec }\end{array}$ & $\begin{array}{l}\text { 2points of damage, } \\
\text { darkness } 2 \mathrm{sec}\end{array}$ & $\begin{array}{l}\text { 3points of damage, } \\
\text { darkness } 2 \text { sec }\end{array}$ \\
\hline$a-x=b$ & Water burst & Water & 2 points of damage & 3 points of damage & 4 points of damage \\
\hline$a \cdot x=b$ & $\begin{array}{l}\text { Necromancy } \\
\text { Touch }\end{array}$ & Death & $\begin{array}{l}2 \text { points of damage, } \\
\text { spinning numbers for } 2 \mathrm{sec}\end{array}$ & $\begin{array}{l}3 \text { points of damage, } \\
\text { spinning numbers for } 3 \mathrm{sec}\end{array}$ & $\begin{array}{l}4 \text { points of damage, } \\
\text { spinning numbers for } 3 \mathrm{sec}\end{array}$ \\
\hline$a / x=b$ & Fireball & Fire & 3 points of damage & 4 points of damage & 5 points of damage \\
\hline$a \cdot x+y=c$ & Energy blast & Energy & 4 points of damage & 5 points of damage & 7 points of damage \\
\hline$a \cdot x-y=c$ & Poison Arrow & Poison & $\begin{array}{l}2 \text { points of damage, } \\
\text { spinning numbers for } 2 \mathrm{sec}\end{array}$ & $\begin{array}{l}3 \text { points of damage, } \\
\text { spinning numbers for } 3 \mathrm{sec}\end{array}$ & $\begin{array}{l}4 \text { points of damage, } \\
\text { spinning numbers for } 3 \mathrm{sec}\end{array}$ \\
\hline$a / x+y=c$ & Life touch & Healing & heal 4 points of damage & heal 5 points of damage & heal 6 points of damage \\
\hline$a / x-y=c$ & Blinding ray & Light & $\begin{array}{l}4 \text { points of damage, white } \\
\text { screen for } 1 \mathrm{sec}\end{array}$ & $\begin{array}{l}4 \text { points of damage, white } \\
\text { screen for } 2 \mathrm{sec}\end{array}$ & $\begin{array}{l}4 \text { points of damage, white } \\
\text { screen for } 2 \mathrm{sec}\end{array}$ \\
\hline$a+x=b+y$ & Blizzard & Water & 5 points of damage & $\begin{array}{l}7 \text { points of damage, freeze } \\
1 \mathrm{sec}\end{array}$ & $\begin{array}{l}9 \text { points of damage, freeze } \\
1 \mathrm{sec}\end{array}$ \\
\hline$a-x=b \cdot y$ & Thunder strike & Energy & 6 points of damage & 8 points of damage & 11 points of damage \\
\hline \multirow[t]{6}{*}{$a+x-z=b \cdot y$} & $\begin{array}{l}\text { Poisonous } \\
\text { vines }\end{array}$ & Poison & & & \\
\hline & Cloud of Death & Death & & & \\
\hline & Firestorm & Fire & & & \\
\hline & Scorching ray & Light & & & \\
\hline & Regeneration & Healing & & & \\
\hline & Aura of Doom & Darkness & & & \\
\hline
\end{tabular}

\section{http://www.ejmste.com}

